\title{
Elucidating the odor-active aroma compounds in alcohol-free beer and their contribution to the worty flavor
}

Article

Published Version

Creative Commons: Attribution 4.0 (CC-BY)

Open access

Piornos, J. A., Balagiannis, D. P., Methven, L., Koussissi, E., Brouwer, E. and Parker, J. K. (2020) Elucidating the odoractive aroma compounds in alcohol-free beer and their contribution to the worty flavor. Journal of Agricultural and Food Chemistry, 68 (37). pp. 10088-10096. ISSN 0021-8561 doi: https://doi.org/10.1021/acs.jafc.0c03902 Available at https://centaur.reading.ac.uk/92873/

It is advisable to refer to the publisher's version if you intend to cite from the work. See Guidance on citing.

To link to this article DOI: http://dx.doi.org/10.1021/acs.jafc.0c03902

Publisher: American Chemical Society

All outputs in CentAUR are protected by Intellectual Property Rights law, including copyright law. Copyright and IPR is retained by the creators or other copyright holders. Terms and conditions for use of this material are defined in the End User Agreement. 


\section{CentAUR}

Central Archive at the University of Reading

Reading's research outputs online 


\title{
Elucidating the Odor-Active Aroma Compounds in Alcohol-Free Beer and Their Contribution to the Worty Flavor
}

\author{
José A. Piornos, Dimitrios P. Balagiannis, Lisa Methven, Elisabeth Koussissi, Eric Brouwer, \\ and Jane K. Parker*
}

Cite This: J. Agric. Food Chem. 2020, 68, 10088-10096

Read Online

ACCESS | Llll Metrics \& More | 国 Article Recommendations ｜ＳＳ Supporting Information

ABSTRACT: Alcohol-free beers (AFBs) brewed by cold-contact fermentation exhibit a flavor reminiscent of wort which affects consumer acceptability. The aims of this study were to identify the odor-active compounds in AFB and elucidate the contribution of these to the overall aroma and worty character of the beer. Using a sensomics approach, 27 odor-active aroma compounds were identified and quantitated using gas chromatography-mass spectrometry. The most odor-active compound was methional (boiled potato-like aroma), followed by 3-methylbutanal (cocoa-like), (E)- $\beta$-damascenone (apple, jam-like), 5-ethyl-3-hydroxy-4-methyl$2(5 \mathrm{H})$-furanone (curry, spicy-like), and phenylacetaldehyde (floral, honey-like). The important contribution of these flavor compounds to the worty and honey aroma of AFB was determined by sensory assessment of the recombinate in a beer-like matrix with omission tests. The role of 5-ethyl-3-hydroxy-4-methyl-2(5H)-furanone in AFB aroma was reported for the first time. The outcomes from this study are of relevance for the brewing industry to design strategies for the reduction of the wortiness of AFB. KEYWORDS: alcohol-free beer, aroma extract dilution analysis, solvent-assisted flavor evaporation, aroma recombination, omission test

\section{INTRODUCTION}

Consumption of alcohol-free beer (AFB) has experienced unprecedented growth over the last few years. This is mainly associated with restrictions in alcohol consumption for reasons such as medical advice (during pregnancy, those with cardiovascular or hepatic diseases, and sport professionals), driving legislation, religious grounds, or health awareness. ${ }^{1}$ As reported by the Brewers of Europe, the trend for the next few years in most European countries is an increase in the consumption of nonalcoholic beverages. ${ }^{2}$ Brewing companies are aware of this, and they are investing in the development of new nonalcoholic products and the improvement of the ones currently at the market.

There are a variety of methods for the production of AFBs, usually classified into two categories: physical and biological methods. ${ }^{3}$ Physical methods, such as vacuum distillation ${ }^{1}$ or membrane separation, ${ }^{4}$ are based on the dealcoholization of a regular alcoholic beer; hence, they require special equipment. On the other hand, biological methods modify the fermentation process aiming to limit the formation of ethanol by using either nontraditional yeasts or genetically modified microorganisms $s^{5}$ or adapting the process conditions, such as fermentation temperature and time. Biological methods present the advantage of generally not requiring any special equipment, thus reducing considerably the initial investment from the brewer and the carbon footprint.

The development of new strains of microorganisms for the brewing industry might raise concerns for both producers and consumers because of the uncertainty that this can generate from the consumers' perspective. Therefore, cold-contact fermentation is a more commonly used method to produce AFB. ${ }^{6}$ This is based on short fermentation time at low temperatures, just above $0{ }^{\circ} \mathrm{C}$, aiming to limit yeast metabolism and thus the formation of ethanol. Unfortunately, the formation of desired flavor compounds such as esters (e.g. 3-methylbutyl acetate, 2-phenylethyl acetate, and ethyl acetate) and higher alcohols (e.g. 3-methyl-1-butanol and 2-phenylethanol) and the reduction of carbonyl compounds are also very limited. ${ }^{7,8}$ Consequently, these beers are characterized by a lack of the appreciated fruity flavor present in lager and other alcoholic beers, and their flavor is commonly described as malty and reminiscent of wort. The literature shows that some Strecker aldehydes, particularly 2-methylbutanal, 3-methylbutanal, and methional have an important role in the negative attributes associated with the malty, worty flavor of these AFBs. ${ }^{9}$ These aldehydes have exceptionally low odor thresholds and impart potent worty, malty, and cocoa-like aromas even at low concentrations. ${ }^{10}$

Despite the findings of the previous work carried out on $\mathrm{AFB},{ }^{9}$ there is no further information about the contribution of other odor-active compounds to the overall aroma of AFB. Following the sensomics approach, over 30 odor-active compounds were identified in two commercial Bavarian wheat beers ${ }^{11}$ and 40 in Bavarian Pilsner-type beers. ${ }^{12}$ Therefore, our hypothesis was that, in addition to the Strecker aldehydes already identified, there are other flavor compounds contributing to the worty flavor of AFBs. Thus, the aim of this

Received: June 20, 2020

Revised: August 14, 2020

Accepted: August 16, 2020

Published: August 16, 2020 
work was to determine the contribution of the odor-active compounds in AFB to the overall aroma by means of quantitative chemical and sensory analyses.

\section{MATERIALS AND METHODS}

Alcohol-Free Beer. An AFB (less than 0.05\% ABV, 100\% Lager malt, bottom fermentation) was brewed, bottled, and pasteurized in Heineken's pilot brewery (Zoeterwoude, The Netherlands) in January 2016 following a standard cold-contact fermentation procedure (brewing conditions not specified). No external flavorings were added. Samples of the wort used to produce this beer were also collected, bottled, and pasteurized. The AFB and wort were stored at $2{ }^{\circ} \mathrm{C}$.

Chemicals. Diethyl ether, dansyl chloride, and saturated alkane standards were purchased from Sigma-Aldrich (Gillingham, Dorset, UK). $O$-(2,3,4,5,6-Pentafluorobenzyl)-hydroxylamine hydrochloride (PFBHA) was purchased from Fluka (Loughborough, UK). The following food-grade aroma compounds were purchased from SigmaAldrich (purity in parenthesis): acetaldehyde ( $\geq 99 \%)$, acetic acid ( $\geq 99.5 \%)$, 2,3-butanedione (97\%), butanoic acid ( $\geq 99 \%)$, (E)- $\beta$ damascenone ( $\geq 98 \%$ ), dimethyl sulfide ( $\geq 99 \%)$, 5-ethyl-3-hydroxy-4methyl-2(5H)-furanone (97\%), 5( or 2)-ethyl-4-hydroxy-2(or 5)methyl-3(2H)-furanone (96\%), ( $\mathrm{Z})$-4-heptenal ( $\geq 98 \%)$, 3-hydroxy4,5-dimethyl-2( $5 H)$-furanone ( $10 \%$ in propylene glycol), 4-hydroxy2,5-dimethyl-3( $2 H)$-furanone $(\geq 98 \%)$, methional ( $\geq 97 \%)$, 2-methoxy-4-methylphenol $(\geq 98 \%)$, 2-methoxyphenol ( $\geq 99 \%)$, 2-methoxy-4-vinylphenol ( $\geq 98 \%)$, 2-methylbutanal ( $\geq 95 \%)$, 3-methylbutanal ( $\geq 97 \%)$, 3-methylbutanoic acid (99\%), 3-methyl-1-butanol ( $\geq 98 \%)$, methylpropanal ( $\geq 98 \%)$, 2,3-pentanedione ( $\geq 96 \%)$, phenylacetaldehyde (10\% in ethanol), 2-phenylacetic acid ( $\geq 99 \%), 2$ phenylethanol ( $\geq 99 \%)$, vanillin $(\geq 97 \%)$, and 4-vinylphenol (10\% in propylene glycol). Encapsulated 3-methyl-2-butene-1-thiol flavor standard $(0.02-4 \mathrm{ng} / \mathrm{g}$ ) was purchased from FlavorActiV (Aston Rowant, UK).

Isolation of Volatile Fractions. For the isolation of volatiles from the AFB and the wort, the procedure described by Langos et al. was employed with slight modifications. ${ }^{11}$ Briefly, the AFB sample (1 $\mathrm{kg}$ ) was extracted with redistilled diethyl ether $(250 \mathrm{~mL} \times 4)$. The organic phases were combined, dried over anhydrous $\mathrm{Na}_{2} \mathrm{SO}_{4}$, and filtered before concentration using a Vigreux distillation column (60 $\mathrm{cm}, 1 \mathrm{~cm}$ i.d.) at $40{ }^{\circ} \mathrm{C}$ until a final volume of approximately $100 \mathrm{~mL}$ was reached. In order to separate the nonvolatile materials from the extract, this concentrated extract was submitted to a high-vacuum distillation process known as the solvent-assisted flavor evaporation $(\mathrm{SAFE})^{13}$ technique at $25{ }^{\circ} \mathrm{C}$ and $10^{-5} \mathrm{~Pa}$. The distillate was fractioned into an acidic and a basic/neutral fraction using $\mathrm{NaHCO}_{3}$ $0.5 \mathrm{M}$ solution $(60 \mathrm{~mL} \times 3)$. After washing with $30 \mathrm{~mL}$ of a saturated $\mathrm{NaCl}$ solution three times, the organic layer was kept for further treatment (basic/neutral organic extract). In parallel, the aqueous phase was acidified to $\mathrm{pH} 2.25 \pm 0.10$ by adding $\mathrm{HCl}$ solution ( 10 or $1 \mathrm{M})$ and extracted using redistilled diethyl ether $(60 \mathrm{~mL} \times 3)$, and the extracts were combined (acidic organic extract). Both basic/ neutral and acidic organic extracts were concentrated using a Kuderna-Danish concentrator at $45{ }^{\circ} \mathrm{C}$ (final volume $\sim 400 \mu \mathrm{L}$ for each extract) and stored at $-80^{\circ} \mathrm{C}$ until use.

Gas Chromatography Analyses of Concentrated Aroma Extracts. In order to identify odor-active compounds in the concentrated aroma extracts, they were analyzed by GC-olfactometry (GC-O) using a 5890 Series II gas chromatograph from Hewlett Packard (Waldbronn, Germany) fitted with an FID detector held at $250{ }^{\circ} \mathrm{C}$. The organic extracts $(2 \mu \mathrm{L})$ were injected (injection port temperature $250^{\circ} \mathrm{C}$ ) in the split mode $(1: 10)$, and two capillaries with different polarity were employed: the Rxi-5Sil MS capillary (30 m, $0.25 \mathrm{~mm}$ i.d., $1.0 \mu \mathrm{m} \mathrm{df}$ ) nonpolar column and a Stabilwax-DA (30 m, $0.25 \mathrm{~mm}$ i.d., $0.25 \mu \mathrm{m}$ df) polar column, both from Restek (Bellefonte, PA, USA). The temperature gradients were set as follows: $40{ }^{\circ} \mathrm{C}$ for $2 \mathrm{~min}$, then a rise of $5{ }^{\circ} \mathrm{C} / \mathrm{min}$ up to $200{ }^{\circ} \mathrm{C}$ and $15{ }^{\circ} \mathrm{C} / \mathrm{min}$ from 200 to $300{ }^{\circ} \mathrm{C}$, and then held for $19 \mathrm{~min}$ for the nonpolar column; $40{ }^{\circ} \mathrm{C}$ for $2 \mathrm{~min}$, then rise of $4{ }^{\circ} \mathrm{C} / \mathrm{min}$ up to $200{ }^{\circ} \mathrm{C}$, then from $200{ }^{\circ} \mathrm{C}$ up to $250{ }^{\circ} \mathrm{C}$ at $15^{\circ} \mathrm{C} / \mathrm{min}$, and then held for $15 \mathrm{~min}$ for the polar column. Helium was used as the carrier gas $(2 \mathrm{~mL} / \mathrm{min})$. The sample was split 1:1 at the end of the column, followed by two untreated silica-fused capillaries of the same dimensions $(1 \mathrm{~m}, 0.32$ $\mathrm{mm}$ i.d.). An ODO II sniffing port from SGE (Ringwood, Victoria, Australia), where the flow was diluted with a moist make up gas, was utilized. Every sample was sniffed in duplicate by at least 3 assessors with one year or more experience in performing GC-O experiments.

The concentrated aroma extracts were also analyzed by gas chromatography-mass spectrometry (GC-MS) using equivalent capillaries and chromatographic conditions as used for the GC-O analyses. The instrument employed in this case was a gas chromatograph model $7890 \mathrm{~A}$ coupled to a 5975C inert XL EI/CI MSD triple axis mass spectroscopy detector and a 7683B Series autosampler, all from Agilent Technologies (Santa Clara, CA, USA). The carrier gas was helium at a constant flow rate of $1 \mathrm{~mL} / \mathrm{min}$. Mass spectra were recorded in the EI mode at an ionization voltage of 70 $\mathrm{eV}$ and a source temperature of $200{ }^{\circ} \mathrm{C}$.

Because of their low-quality signal in the MS chromatograms, some compounds were identified by GC-accurate-mass time of flight-mass spectrometry (GC-ToF-MS), which is a more sensitive detection technique. The organic extracts $(1 \mu \mathrm{L})$ were injected manually in both splitless and split (1:10) mode (injection port temperature $250{ }^{\circ} \mathrm{C}$ ). The oven temperature in the 6890 gas chromatograph (Agilent) was initially set at $40^{\circ} \mathrm{C}$ for $2 \mathrm{~min}$, then $5{ }^{\circ} \mathrm{C} / \mathrm{min}$ to $300{ }^{\circ} \mathrm{C}$, and held at the final temperature for $15 \mathrm{~min}$. The carrier gas employed was helium at a flowrate of $0.8 \mathrm{~mL} / \mathrm{min}$. A Micromass GCT TOF mass spectrometer from Waters (Milford, MA, USA) was used as the detector. Mass Spectra were recorded in the EI mode at an ionization voltage of $70 \mathrm{eV}$ and a source temperature of $180{ }^{\circ} \mathrm{C}$. The samples were analyzed using two columns of different polarity.

HS-SPME-GC-O. The method described by Lignou et al. was used with modifications. ${ }^{14}$ AFB $(100 \mathrm{~g})$ was weighed into a $500 \mathrm{~mL}$ screw-capped Erlenmeyer flask. The flask was placed in a water bath at $45{ }^{\circ} \mathrm{C}$, and after equilibration for $10 \mathrm{~min}$, divinylbenzene/Carboxen/ polydimethylsiloxane (DVB/CAR/PDMS) and Carboxen/polydimethylsiloxane (CAR/PDMS) fibers (Supelco, Bellefonte, PA, USA) were exposed simultaneously to the headspace for $30 \mathrm{~min}^{15} \mathrm{~A}$ preholed septum was used to hold and expose the fibers. After extraction, the fibers were desorbed into the injection port of the GCO-FID as described in the previous section: first, the DVB/CAR/ PDMS fiber and then the CAR/PDMS fiber, for 2 min each. Volatiles were cryo-focused in the GC column by dry ice during desorption, as reported previously. ${ }^{14}$ For some of these GC analyses, the initial temperature of the $\mathrm{GC}$ run was kept at $27^{\circ} \mathrm{C}$ for $10 \mathrm{~min}$ in order to improve the separation of the highly volatile compounds.

Identification of Odor-Active Compounds. Mass spectral libraries, such as NIST 2011 and Inramass (INRA, France), were used for primary identification using ChemStation software (Agilent). Then, linear retention indices (LRIs) were calculated from the retention time of $n$-alkanes obtained by analyses performed using the same conditions as for sample analyses. Authentic compounds were analyzed using the same chromatographic method to confirm their identity by LRI comparison and odor quality. When identification of GC-MS data from the AFB sample was difficult, the GC-O and GCMS data from the wort samples were considered. Once a candidate compound was found in the wort, its identity was confirmed in the AFB by applying the criteria above.

Aroma Extract Dilution Analysis. Basic/neutral and acidic extracts of the AFB were diluted stepwise 1:1 using redistilled diethyl ether and assessed by GC-O using the nonpolar column, as described in section "Gas Chromatography Analyses of Concentrated Aroma Extracts". The flavor dilution (FD) factor for a specific odor region is defined as the highest dilution at which the odor can still be perceived at the sniffing port of GC-O.

Quantitation of Methylpropanal, 2-Methylbutanal, 3-Methylbutanal, Phenylacetaldehyde, (Z)-4-Heptenal, and Methional. A previously reported derivatization technique was used, with slight modifications. ${ }^{16}$ Samples were prepared under a $\mathrm{CO}_{2}$ atmosphere $\left(0.075 \% \mathrm{O}_{2}\right)$ to prevent the degradation of aldehydes. 
Beer samples $(30.0 \mathrm{~g})$ were weighed, and $10 \mu \mathrm{g} / \mathrm{L}$ of internal standard (benzaldehyde- $d_{6}, 2$-methylbutanal- $d_{10}$, and 4-methylthiobutanal, obtained by spiking $30 \mu \mathrm{L}$ of a $10.0 \mathrm{mg} / \mathrm{L}$ standard solution prepared in absolute ethanol) was added using a gas-tight syringe. Aliquots (4.0 g) of the sample were transferred to $10 \mathrm{~mL}$ SPME vials and then placed in an MPS autosampler (Gerstel GmbH, Mülheim an der Ruhr, Germany) provided with an SPME fiber ( $65 \mu \mathrm{m}$, PDMS/DVB, Supelco). First, the SPME fiber was exposed to the headspace of the vial containing $14 \mathrm{~g}$ of PFBHA solution $(200 \mathrm{mg} / \mathrm{L})$, for $10 \mathrm{~min}$ at 30 ${ }^{\circ} \mathrm{C}$, and then exposed to the headspace of the vial containing the sample $\left(30 \mathrm{~min}\right.$, at $\left.30^{\circ} \mathrm{C}\right)$. The derivatized volatiles were desorbed at the injection port (held at $250{ }^{\circ} \mathrm{C}$ ) of an Agilent $7890 \mathrm{~A}$ gas chromatograph, equipped with a VF-17MS column $(30 \mathrm{~m}, 0.25 \mathrm{~mm}$, $0.25 \mu \mathrm{m} \mathrm{df}$ ) from Agilent. A split ratio of 5 was applied, and helium at $1 \mathrm{~mL} / \mathrm{min}$ was used as the carrier gas. The initial temperature in the oven was held at $50{ }^{\circ} \mathrm{C}$ for $2 \mathrm{~min}$, raising up to $100{ }^{\circ} \mathrm{C}$ at $5{ }^{\circ} \mathrm{C} / \mathrm{min}$ and from 100 to $260{ }^{\circ} \mathrm{C}$ at $10{ }^{\circ} \mathrm{C} / \mathrm{min}$, maintaining the final temperature for $2 \mathrm{~min}$. The Agilent 5975C inert XL EI/CI mass spectrometer with a Triple Axis Detector was set up for negative chemical ionization using methane as the reagent gas $(1.5 \mathrm{~mL} / \mathrm{min}$, ionized at $230 \mathrm{eV}$ ). The ionization energy was $70 \mathrm{eV}$, and the source temperature was $230{ }^{\circ} \mathrm{C}$. For all aldehydes targeted in this method, a suitable ion fragment was chosen. As most PFBHA-aldehyde derivative compounds, that is, pentafluorobenzyl oximes, consist of two peaks (syn- and antisomers), the peak areas were summed. Calibration curves for aldehyde quantitation were prepared by standard addition to the AFB.

Quantitation of Carboxylic Acids, Alcohols, and (E)- $\beta$ Damascenone. Butanoic acid, 3-methylbutanoic acid, 3-methyl-1butanol, 2-phenylethanol, 2-phenylacetic acid, and (E)- $\beta$-damascenone were analyzed by HS-SPME-GC-MS. A mixture of internal standards (3-methyl-1-pentanol for 3-methyl-1-butanol, 2-ethylbutanoic acid for butanoic and 3-methylbutanoic acids, $\beta$-ionone for $(E)$ $\beta$-damascenone, and benzoic acid for 2-phenylethanol and 2phenylacetic acid; $25 \mu \mathrm{L}$ at $1000 \mathrm{mg} / \mathrm{L}$ in absolute ethanol) was added to $25 \mathrm{~mL}$ of AFB. An aliquot $(3 \mathrm{~g}$ ) was poured into a $20 \mathrm{~mL}$ screw-capped SPME vial, and $2.75 \mathrm{~g}$ of $\left(\mathrm{NH}_{4}\right)_{2} \mathrm{SO}_{4}$ and $0.75 \mathrm{~g}$ of $\mathrm{NaH}_{2} \mathrm{PO}_{4} \cdot \mathrm{H}_{2} \mathrm{O}$ were added in order to increase the release of volatiles. ${ }^{17}$ The vials were incubated at $35{ }^{\circ} \mathrm{C}$ for $15 \mathrm{~min}$ before exposure to the SPME fiber (DVB/CAR/PDMS) for $30 \mathrm{~min}$. The fiber was then desorbed into the GC inlet port at $250{ }^{\circ} \mathrm{C}$ for $20 \mathrm{~min}$. A Stabilwax-DA (dimensions described previously) polar column was used, keeping it at $40{ }^{\circ} \mathrm{C}$ for $2 \mathrm{~min}$, then $10{ }^{\circ} \mathrm{C} / \mathrm{min}$ to $120^{\circ} \mathrm{C}$ for 1 min, and then $4{ }^{\circ} \mathrm{C} / \mathrm{min}$ to $250{ }^{\circ} \mathrm{C}$ for $5 \mathrm{~min}$. Helium was used as the carrier gas. The chromatograph and the MS detection conditions were the same as in section "Gas Chromatography Analyses of Concentrated Aroma Extracts”. Calibration curves were prepared using the AFB matrix.

Quantitation of Dimethyl Sulfide and Acetic Acid. The method described in the previous section was modified for the quantitation of these compounds. In both cases, the addition of salts was omitted. For dimethyl sulfide, the beer sample $(20 \mathrm{~mL})$ was spiked with $1 \mu \mathrm{L}$ of 1,4-dichlorobenzene (100 mg/L in diethyl ether) as the internal standard, and $5 \mathrm{~mL}$ aliquots were analyzed. For acetic acid, the aliquot $(5 \mathrm{~mL})$ was acidified with $250 \mu \mathrm{L}$ of $\mathrm{HCl}(6 \mathrm{M})$, and $50 \mu \mathrm{L}$ of acetic acid- $d_{3}(1000 \mathrm{mg} / \mathrm{L})$ was used as the internal standard. In both cases, an Agilent J\&W HP-5MS column ( $30 \mathrm{~m}, 0.25$ $\mathrm{mm}, 0.25 \mu \mathrm{m} \mathrm{df}$ ) was employed, and the following gradient was applied: $40{ }^{\circ} \mathrm{C}$ for $2 \mathrm{~min}$, then $5{ }^{\circ} \mathrm{C} / \mathrm{min}$ to $100{ }^{\circ} \mathrm{C}$, and then $12{ }^{\circ} \mathrm{C} /$ min to $300{ }^{\circ} \mathrm{C}$, keeping this for $10 \mathrm{~min}$. Calibration standards were prepared using the AFB as the matrix.

Quantitation of 2,3-Butanedione, 2,3-Pentanedione, and Acetaldehyde. First, the ethanol content of the samples was adjusted to $5 \% \mathrm{v} / \mathrm{v}$ by adding absolute ethanol. The sample $(250 \mathrm{~mL}$, kept at $0-10{ }^{\circ} \mathrm{C}$ ) was mixed with $2.0 \mathrm{~mL}$ of cold 2,3-hexanedione internal standard solution and left to stand for $5 \mathrm{~min}$. For the vicinal diketones, an aliquot $(5 \mathrm{~mL})$ of the sample was transferred into a 10 $\mathrm{mL}$ vial, and the headspace was analyzed by gas chromatography using an electron capture detector. Volatiles in the headspace were collected using an autosampler by trapping them into a Supelco Tenax trap, then desorbed, and cryo-focused before injection. 2,3-Hexanedione was used as the internal standard for the vicinal diketones. This was prepared by diluting $150 \mu \mathrm{L}$ of $90 \%$ 2,3-hexanedione in $100 \mathrm{~mL}$ of ethanol. Then, $10.0 \mathrm{~mL}$ of this stock solution was diluted further with $50 \mathrm{~mL}$ of ethanol and topped up to $1000 \mathrm{~mL}$ with water.

In the case of acetaldehyde, a gas chromatograph fitted with a DBWaxETR ( $60 \mathrm{~m}, 0.32 \mathrm{~mm}, 1 \mu \mathrm{m} \mathrm{df}$ ) capillary column and an FID (flame ionization detector) was used for the analysis of the headspace. 1-Butanol was utilized as the internal standard. Calibration standards of 2,3-butanedione, 2,3-pentanedione, and acetaldehyde were prepared in 5\% ethanol/water.

Quantitation of Furanones and Vanillin. After the AFB sample was degassed and filtered, $1 \mu \mathrm{L}$ was injected into an Acquity UPLC chromatograph, coupled to a Xevo TQ-S tandem triple quadrupole MS detector from Waters. The same Stabilwax-DA column as in previous methods was employed for these analyses (column temperature $\left.50{ }^{\circ} \mathrm{C}\right)$. The mobile phase composed of water $(0.1 \%$ formic acid) as solvent $\mathrm{A}$ and acetonitrile $(0.1 \%$ formic acid) as solvent $\mathrm{B}$. The flow rate was set at $0.25 \mathrm{~mL} / \mathrm{min}$, and the following gradient was used: $95-70 \%$ A for $7 \mathrm{~min}$, further decreased to $5 \% \mathrm{~A}$ after $3 \mathrm{~min}$, kept for $2 \mathrm{~min}$, then increased to $95 \% \mathrm{~A}$ in $1 \mathrm{~min}$, and then held for $3 \mathrm{~min}$ (total run time $16 \mathrm{~min}$ ). The following settings were applied to the detector: source temperature $150{ }^{\circ} \mathrm{C}$, cone gas flow $150 \mathrm{~L} / \mathrm{h}$, collision gas flow $0.21 \mathrm{~mL} / \mathrm{h}$, desolvation temperature $600{ }^{\circ} \mathrm{C}$, and desolvation gas flow $1000 \mathrm{~L} / \mathrm{h}$. Chromatograms were acquired using multiple reaction monitoring (MRM) in the positive mode, with different settings for every compound: 3-hydroxy-4,5dimethyl-2(5H)-furanone (retention time $4.13 \mathrm{~min}$, MS/MS transition $129.13 \rightarrow$ 82.18), 5-ethyl-4-hydroxy-2-methyl-3(2H)furanone $(5.33 \mathrm{~min}, 143.13 \rightarrow 69.07)$, vanillin $(5.71 \mathrm{~min}, 153.10$ $\rightarrow$ 93.10), and 5-ethyl-3-hydroxy-4-methyl-2(5H)-furanone (5.90 $\min , 143.13 \rightarrow 69.07)$. The cone voltage and collision energy were kept at 20 and $10 \mathrm{~V}$, respectively, for all the compounds. The calibration curves were built by standard addition using the AFB matrix. No internal standard was used for this analysis.

Quantitation of 4-Vinylphenol. After degassing an aliquot of AFB by using an ultrasound water bath and filtering it $(0.22 \mu \mathrm{m}$ pore size), the sample $(10 \mu \mathrm{L})$ was injected and analyzed using an Acquity UPLC from Waters (Milford, MA, USA) coupled to an Acquity UPLC FLR fluorescence detector. The separation was performed at $40{ }^{\circ} \mathrm{C}$ using an Acquity UPLC BEH C18 column (1.7 $\mu$ m particle size, 2.1 i.d. $\times 150 \mathrm{~mm}$ ). The chromatographic signal was recorded at $257 \mathrm{~nm}$ for excitation and $334 \mathrm{~nm}$ for emission. An aqueous solution of $\mathrm{NaH}_{2} \mathrm{PO}_{4}$ ( $\mathrm{pH}$ 2.7) was used as mobile phase $\mathrm{A}$ and acetonitrile as mobile phase $\mathrm{B}$. The flow rate was kept constant at $0.250 \mathrm{~mL} / \mathrm{min}$, and the following gradient was applied: $95 \% \mathrm{~A}$ for $2 \mathrm{~min}$, decreased to $10 \%$ A to 19 min, then kept constant for $23 \mathrm{~min}$, increased to $95 \%$ A to $23.5 \mathrm{~min}$, and kept constant for $26 \mathrm{~min}$. The calibration curve was built by standard addition using the AFB matrix.

Quantitation of 2-Methoxy-4-vinylphenol. AFB samples (20 $\mu \mathrm{L})$ were injected in an HPLC system fitted with a SUPELCOSIL Abz+ $(250 \times 4.6 \mathrm{~mm})$ column and a $2 \mathrm{~cm}$ long column guard with similar characteristics. The column oven was kept at $25^{\circ} \mathrm{C}$, and the flowrate was constant at $1.0 \mathrm{~mL} / \mathrm{min}$. The eluents used were methanol/citrate buffer (0.05 M, pH 5.40) 1:1 (mobile phase A) and methanol (mobile phase B). The samples were eluted at $100 \% \mathrm{~A}$ for the first $20 \mathrm{~min}$, then decreased to $50 \%$ in $0.1 \mathrm{~min}$, kept for $9.9 \mathrm{~min}$, increased to $100 \%$ in $0.1 \mathrm{~min}$, and kept for $7.9 \mathrm{~min}$. The total run time was $38 \mathrm{~min}$. Detection was carried out by using a UV detector at 260 $\mathrm{nm}$. Calibration standards were prepared in methanol. No internal standard was used in this analysis.

Quantitation of 2-Methoxyphenol, 2-Methoxy-4-methylphenol, and 4-Hydroxy-2,5-dimethyl-3(2H)-furanone. For the quantitation of 2-methoxyphenol and 2-methoxy-4-methylphenol, the method published by Beaudry et al. was applied, with modifications. ${ }^{18}$ Acetone $(500 \mu \mathrm{L})$ was added to $100 \mu \mathrm{L}$ of beer, vortexed for $1 \mathrm{~min}$, and centrifuged at $13,700 \mathrm{~g}$ for $10 \mathrm{~min}$. Then, the supernatant was transferred to a new vial and mixed with $200 \mu \mathrm{L}$ of dansyl chloride solution $(1 \mathrm{mg} / \mathrm{mL}$ in acetone) and $40 \mu \mathrm{L} \mathrm{NaOH} 0.1 \mathrm{M}$. The dansylated sample $(5 \mu \mathrm{L})$ was injected into a LC-ESI-MS/MS system 
consisting of a 1260 Infinity HPLC coupled to a 6410 Triple Quad LC/MS detector, all from Agilent (Santa Clara, CA, USA). An Agilent Zorbax SB-18 $(2.1 \times 100 \mathrm{~mm}, 1.8 \mu \mathrm{m})$ column was utilized, and a solution containing acetonitrile, water, and formic acid (65/35/0.1, in volume) was used as the mobile phase (constant flow rate $0.35 \mathrm{~mL} /$ $\min )$. The detector was set to the positive mode, and the signal was recorded using dynamic MRM under these conditions: 2-methoxyphenol (fragmentor voltage $150 \mathrm{~V}$, quantitative transition $358.1 \rightarrow$ 171.1 (collision energy $20 \mathrm{~V}$ ), and qualitative transition $358.1 \rightarrow$ $156.1(43 \mathrm{~V})$ ) and 2-methoxy-4-methylphenol (170 V, 372.1 $\rightarrow 171.1$ $(23 \mathrm{~V})$, and $372.1 \rightarrow 156.1(45 \mathrm{~V})$ ). For 4-hydroxy-2,5-dimethyl$3(2 \mathrm{H})$-furanone, the derivatization reaction was not required and thus omitted. The MRM settings for this compound were $80 \mathrm{~V}, 129.1 \rightarrow$ $43.1(10 \mathrm{~V})$, positive mode. Calibration standards were prepared in the AFB. No internal standards were used for this method.

Aroma Recombination and Omission Sensory Tests. Aroma recombinates were prepared using an AFB-model comprising a mixture of sugars $(7.2 \mathrm{~g} / \mathrm{L}$ glucose, $2.1 \mathrm{~g} / \mathrm{L}$ fructose, $0.6 \mathrm{~g} / \mathrm{L}$ sucrose, $26.9 \mathrm{~g} / \mathrm{L}$ maltose, and $3.6 \mathrm{~g} / \mathrm{L}$ maltotriose) in carbonated water, as described previously. ${ }^{10}$ The aroma compounds were dissolved in propylene glycol at a concentration $10^{4}$ times higher than in the actual AFB. For 3-methyl-2-butene-1-thiol, the encapsulated flavor standard $(60 \mathrm{mg})$ was dissolved in $500 \mu \mathrm{L}$ of a mixture of $30 \% \mathrm{v} / \mathrm{v}$ ethanol and $70 \% \mathrm{v} / \mathrm{v}$ propylene glycol and added to the recombinate at $150 \mu \mathrm{L} /$ $100 \mathrm{~mL}(0.0036-0.72 \mathrm{ng} / \mathrm{L}$ final concentration as specified by the supplier). Along with the aroma recombinate containing all the compounds identified and quantitated, nine additional recombinates were prepared with one or two compounds missing for the omission tests (omitted recombinates). These samples $(5 \mathrm{~mL})$, together with the AFB and its wort (diluted 1:1 with filtered tap water in order to match the overall intensity of its aroma with the AFB's aroma) were poured into $27 \mathrm{~mL}$ screw-capped clear glass vials (height $72 \mathrm{~mm}$, internal diameter $23 \mathrm{~mm}$ ). The samples were prepared $2 \mathrm{~h}$ prior to the sensory evaluation to allow headspace equilibration and presented at a temperature between 9 and $14{ }^{\circ} \mathrm{C}$.

Ten screened and trained sensory panelists from the Sensory Science Centre of the University of Reading, with a minimum of six month experience in sensory evaluation of flavor, participated in quantitative descriptive analysis (QDA) tests. In the initial vocabulary session, the panelists were asked to describe the aroma of the samples, followed by a discussion to work towards a consensus vocabulary. In subsequent sessions, the consensus vocabulary was confirmed by standardizing aroma descriptors against various references (Table 1). In the following scoring sessions, the panelists were asked to open the vials, sniff the samples, and score against each descriptor on unstructured line scales $(0-100)$. The sensory assessments were carried out in duplicates on different days, in individual sensory booths under red light at a room temperature of $20^{\circ} \mathrm{C}$. The samples were split into two groups (maximum 13 per day) (Table 4) and presented monadically, in a balanced order and coded with three-digit numbers. In the first sample set, the AFB, the diluted wort, the full recombinate, and five omitted recombinates were assessed, whereas in the second set, the samples were the full recombinate and four omitted recombinates. Between samples, a time delay (30 s) was applied, and the panelists were supplied with filtered water for refreshment if needed. The project was designed, presented, and data captured using Compusense Cloud (Compusense Inc., Guelph, ON, Canada). The QDA data were analyzed in SenPAQ 5.01 (Qi Statistics, Reading, UK) using two-way ANOVA, with samples fitted as a fixed effect and panelists as a random effect, and both treatment effects were tested against the sample by assessor interaction. Significant differences between sample pairs were tested using Fisher's LSD multiple comparison test at $p=0.05$. The panel performance was monitored by using the following parameters: nondiscrimination of attributes, nonreproducibility of attributes, and attributes causing interaction. These were obtained by one-way ANOVA fitted to each assessor (data not shown).
Table 1. References for the Aroma Attributes in AFB, Its Recombinate, and Diluted Wort

\begin{tabular}{|c|c|c|}
\hline $\begin{array}{l}\text { aroma } \\
\text { attribute }\end{array}$ & reference & brand and supplier \\
\hline malt, cereal & $\begin{array}{l}\text { light dried malt extract } \\
\text { dissolved in warm water } \\
(25 \mathrm{~g} / \mathrm{L})\end{array}$ & $\begin{array}{l}\text { Ritchies (Ritchie Products } \\
\text { Limited, Burton-on-Trend, UK) }\end{array}$ \\
\hline potato & $\begin{array}{l}\text { solution of methional in water } \\
(85 \mu \mathrm{g} / \mathrm{L})\end{array}$ & Sigma-Aldrich (Gillingham, UK) \\
\hline $\begin{array}{l}\text { hay (green } \\
\text { tea) }\end{array}$ & green tea loose leaves & Local supplier \\
\hline $\begin{array}{l}\text { honey } \\
\text { (hot) }\end{array}$ & $\begin{array}{l}\text { wildflower honey, dissolved in } \\
\text { boiling water }\end{array}$ & Rowse (Wallingford, UK) \\
\hline floral & $\begin{array}{l}\text { geraniol }(98 \%) \text { diluted in water } \\
(50 \mu \mathrm{L} / \mathrm{L})\end{array}$ & Sigma-Aldrich (Gillingham, UK) \\
\hline prunes & dried pitted prunes & $\begin{array}{l}\text { Morrisons Savers (Wm Morrison } \\
\text { Supermarkets PLC., Bradford, } \\
\text { UK) }\end{array}$ \\
\hline $\begin{array}{l}\text { dark brown } \\
\text { sugar }\end{array}$ & dark brown soft sugar & $\begin{array}{l}\text { Billington's (The Silver Spoon } \\
\text { Company, Peterborough, UK) }\end{array}$ \\
\hline $\begin{array}{l}\text { apple } \\
\text { (stewed) }\end{array}$ & $\begin{array}{l}\text { Bramley apples, peeled, cut, } \\
\text { and cooked for } 30 \mathrm{~min}\end{array}$ & Local supplier \\
\hline yeast & $\begin{array}{l}\text { dried easy bake yeast, } 3.5 \mathrm{~g} \\
\text { dissolved in } 200 \mathrm{~mL} \text { of warm } \\
\text { water }\end{array}$ & $\begin{array}{l}\text { Allinson's (Allinson Flour, } \\
\text { Peterborough, UK) }\end{array}$ \\
\hline $\begin{array}{l}\text { curry, } \\
\text { fenugreek }\end{array}$ & ground fenugreek & $\begin{array}{l}\text { Schwartz ( } \\
\text { McCormick \& Company, Inc., } \\
\text { Hunt Valley, MD, USA) }\end{array}$ \\
\hline
\end{tabular}

\section{RESULTS AND DISCUSSION}

Identification of the Key Aroma Compounds in AFB. For the present study, a noncommercial AFB was chosen because of its characteristic worty aroma. This AFB was brewed, bottled, and pasteurized in Heineken's pilot plant brewery. For the extraction of volatile compounds, two different methodologies were applied: SAFE and SPME. After sniffing both acidic and basic/neutral SAFE extracts by GC-O, some common highly volatile aroma compounds had not been detected in our beer samples, so two-fiber SPMEGC-O was applied in order to trap a greater amount and variety of these highly volatile aroma compounds. Elmore et al. demonstrated that the use of two SPME fibers simultaneously increased the number of volatile compounds extracted and their concentration. ${ }^{15}$ The aroma extract dilution analysis was used as a criterion to reject the least important compounds. Table 2 shows the most odor-active compounds (those with an FD factor $\geq 16$ ) found in the SAFE extracts, as well as those from the SPME experiments. The chromatograms and olfactograms (i.e. the list of odor regions and LRI obtained by GC-O) of SAFE extracts from the wort were used as a guide because, in most cases, the same odor regions were found in both products, and the wort provided a more concentrated extract. Moreover, flavor compounds at the same LRI were usually found at higher intensity in the wort. Thus, these compounds were primarily identified in the wort, and then, their presence was confirmed in the AFB. The full olfactograms for both the AFB and the wort are presented in Supporting Information Tables S1.1-S1.4. Twenty-eight odor-active regions perceived at the sniffing port were present at high FD factor. Twenty-six odor-active compounds were identified by considering their mass spectra, odor quality at the sniffing port, and LRI. Because 3-methyl-2-butene-1-thiol did not produce any chromatographic peak or mass spectrum, this was identified based on its characteristic aroma and LRI on two columns of different polarity and by comparison against an authentic standard. ${ }^{19}$ Unfortunately, one compound (com- 
Table 2. Aroma Compounds (FD $\geq 16$ ) Identified by GC-O in SAFE and SPME Extracts

\begin{tabular}{|c|c|c|c|c|c|c|c|}
\hline \multirow[b]{2}{*}{ no } & \multirow[b]{2}{*}{ compound } & \multirow[b]{2}{*}{ odor description ${ }^{b}$} & \multirow[b]{2}{*}{ fraction $^{c}$} & \multicolumn{2}{|c|}{$\mathrm{LRI}^{a}$} & \multirow[b]{2}{*}{ FD factor ${ }^{d}$} & \multirow[b]{2}{*}{ refs } \\
\hline & & & & Rxi-5 & Stabilwax & & \\
\hline 1 & acetaldehyde & green apple & spme & 500 & 718 & na & 12 \\
\hline 2 & dimethyl sulfide & sweetcorn & spme & 530 & 768 & na & 12,20 \\
\hline 3 & methylpropanal & cocoa, ripen melon & spme & 569 & 806 & na & 21 \\
\hline 4 & 2,3-butanedione & creamy, butter & $\mathrm{b}$ & 587 & 1001 & 512 & 22,36 \\
\hline 5 & acetic acid & vinegar & $\mathrm{a}$ & 589 & 1460 & 128 & 11 \\
\hline 6 & 3-methylbutanal & cocoa & a, spme & 642 & 930 & 32 & $9,12,21,22$ \\
\hline 7 & 2-methylbutanal & cocoa & spme & 651 & 924 & na & $9,21,22$ \\
\hline 8 & 2,3-pentanedione & creamy, butter & spme & 706 & 1045 & na & 22 \\
\hline 9 & 3-methyl-1-butanol & beer, malt & $a, b$ & 730 & 1215 & 16 & $1,11,12,22,36$ \\
\hline 10 & butanoic acid & cheese & $\mathrm{a}$ & 795 & 1642 & 256 & $11,12,36$ \\
\hline 11 & 3-methyl-2-butene-1-thiol ${ }^{e}$ & sulfur, cannabis & spme & 822 & 1100 & na & 37 \\
\hline 12 & 3-methylbutanoic acid & cheese & $\mathrm{a}$ & 861 & 1684 & 128 & $11,12,22,36$ \\
\hline 13 & (Z)-4-heptenal & fishy & spme & 894 & 1228 & na & 23 \\
\hline 14 & methional & boiled potato & $a, b$ & 922 & 1468 & 512 & $9,11,20,22,36$ \\
\hline 15 & 4-hydroxy-2,5-dimethyl-3(2H)-furanone & candy floss, caramel & $\mathrm{a}$ & 1046 & 2047 & 32 & $11,12,22,36$ \\
\hline 16 & phenylacetaldehyde & floral, honey & $\mathrm{a}, \mathrm{b}$ & 1054 & 1667 & 16 & 21,22 \\
\hline 17 & 2-methoxyphenol & smoky, roasted & $a, b$ & 1096 & 1881 & 128 & $11,12,22,36$ \\
\hline 18 & 3-hydroxy-4,5-dimethyl-2(5H)-furanone & curry, spicy & $a, b$ & 1112 & 2208 & 256 & $11,12,22,31$ \\
\hline 19 & 2-phenylethanol & rose, honey & $a, b$ & 1126 & 1934 & 64 & $1,11,12,22,36$ \\
\hline 20 & 5-ethyl-4-hydroxy-2-methyl-3(2H)-furanone & candy floss, caramel & $\mathrm{a}$ & 1149 & 2096 & 32 & 12,22 \\
\hline 21 & 5-ethyl-3-hydroxy-4-methyl-2(5H)-furanone & curry, spicy & $a, b$ & 1188 & 2378 & 1024 & 22,31 \\
\hline 22 & 2-methoxy-4-methylphenol & smoky, spicy & $a, b$ & 1192 & 1976 & 512 & \\
\hline 23 & 4-vinylphenol & smoky, leather & $a, b$ & 1213 & 2400 & 512 & 11,22 \\
\hline 24 & 2-phenylacetic acid & floral, urine & $\mathrm{a}$ & 1247 & 2631 & 256 & 11,12 \\
\hline 25 & 2-methoxy-4-vinylphenol & smoky, cloves & $\mathrm{b}$ & 1309 & 2211 & 16 & $1,11,12,22,36$ \\
\hline 26 & $(E)$ - $\beta$-damascenone & apple, jam & $\mathrm{b}$ & 1378 & 1849 & 64 & $11,12,22,36$ \\
\hline 27 & vanillin & vanilla & a & 1404 & 2604 & 512 & 11,36 \\
\hline 28 & unknown & plastic, rubber & $\mathrm{a}$ & 1420 & & 128 & \\
\hline
\end{tabular}

${ }^{a}$ Linear retention index. ${ }^{b}$ Most frequent odor descriptors used at the sniffing port. ${ }^{c}$ Compounds perceived in acidic (a), neutral/basic (b) fractions, and/or by HS-SPME-GC-O (spme). ${ }^{d}$ Flavor dilution factor; na for not applicable. ${ }^{e}$ Compound identified considering odor quality and linear retention indices.

pound no. 28 in Table 2: $\mathrm{LRI}_{\mathrm{Rxi}-5}$ 1420, plastic, rubber aroma) remained unidentified. The LRIs for the compounds identified were calculated from two columns of different polarity and confirmed with reference standards.

The compounds with highest FD factors in the basic/neutral and acidic fractions were 5-ethyl-3-hydroxy-4-methyl-2(5H)furanone (21) (FD factor 1024), followed by 2,3-butanedione (4), methional (14), 2-methoxy-4-methylphenol (22), and 4vinylphenol (23), all with FD factors of 512 (Table 2). However, it is noted that 2,3-butanedione was only perceived in the basic/neutral fraction, and vanillin only in the acidic fraction. There were other odor-active compounds that were only detected by SPME-GC-O. These were acetaldehyde (1), dimethyl sulfide (2), methylpropanal (3), 2,3-pentanedione $(8)$, and $(Z)$-4-heptenal (13), previously reported in beer $^{12,20-22}$ and barley malt. ${ }^{23}$ Using the low temperature program for SPME-GC-O described in section "HS-SPMEGC-O”, 2-methylbutanal (7) could be separated from its isomer 3-methylbutanal (6) and thus differentiated at the sniffing port.

The twenty-six compounds identified were quantitated by different analytical methods (Table 3 ). The compounds with highest concentrations were 2-phenylethanol $(20,700 \mu \mathrm{g} / \mathrm{L})$, acetic acid $(13,500 \mu \mathrm{g} / \mathrm{L}), 2$-phenylacetic acid $(1930 \mu \mathrm{g} / \mathrm{L})$, and acetaldehyde $(1200 \mu \mathrm{g} / \mathrm{L})$. On the other hand, the ones with the lowest concentrations were $(Z)$-4-heptenal $(0.063 \mu \mathrm{g} /$ $\mathrm{L}), 2$-methoxy-4-methyphenol $(1.15 \mu \mathrm{g} / \mathrm{L})$, and 2,3-pentane- dione (4.1 $\mu \mathrm{g} / \mathrm{L})$. 3-Methyl-2-butene-1-thiol was not successfully quantitated in AFB. As concentrations are not a direct measurement of the potency of aroma compounds, this was standardized by calculating odor activity values (OAV), that is, the ratio of concentrations and odor detection thresholds (Table 3). Fourteen compounds showed OAVs higher than 1, indicating that their concentration was higher than the detection threshold and that they were likely to contribute to the aroma of AFB. The compound with the highest OAV was methional (OAV 181), followed by 3-methylbutanal (OAV 62), (E)- $\beta$-damascenone (OAV 45), 5-ethyl-3-hydroxy4-methyl-2(5H)-furanone (OAV 36), and phenylacetaldehyde (OAV 29).

It is interesting that the rankings of odor-active compounds according to their FD factor and OAV do not match. Compounds with high FD factors, such as 2-methoxy-4methylphenol (22), 4-vinylphenol (23), or vanillin (27), were on the bottom half of the OAV ranking, all of them below 1 (Table 3). The opposite was observed for 3-methylbutanal, with a concentration 62 times higher than its threshold, although its FD factor was only 32. It must be taken into consideration that FD factors give an approximate idea of the importance of aroma compounds present in the solvent extract prepared from the AFB and not in the AFB itself. This was mainly attributed to different factors, such as different extraction yields for the different compounds from diethyl ether, differences in the loss rate during concentration steps, 
Table 3. Concentrations and OAV of Aroma Compounds in AFB

\begin{tabular}{|c|c|c|c|}
\hline compound & concentration $^{a},(\mu \mathrm{g} / \mathrm{L})$ & detection threshold ${ }^{b},(\mu \mathrm{g} / \mathrm{L})$ & OAV \\
\hline methional & $85.4 \pm 1.22$ & 0.47 & 181 \\
\hline 3-methylbutanal & $38.4 \pm 0.45$ & 0.61 & 62 \\
\hline$(E)$ - $\beta$-damascenone & $10.4 \pm 0.87$ & 0.23 & 45 \\
\hline 5-ethyl-3-hydroxy-4-methyl-2( $5 \mathrm{H})$-furanone & $42.3 \pm 2.02$ & 1.17 & 36 \\
\hline phenylacetaldehyde & $160 \pm 7.34$ & 5.42 & 29 \\
\hline acetaldehyde & $1200 \pm 55$ & 45.8 & 26 \\
\hline 2-phenylethanol & $20,700 \pm 1540$ & 1880 & 11 \\
\hline methylpropanal & $24.0 \pm 0.46$ & 4.3 & 6 \\
\hline (Z)-4-heptenal & $0.063 \pm 0.0043$ & 0.016 & 4 \\
\hline 3-methyl-1-butanol & $233 \pm 2.59$ & 77 & 3 \\
\hline 5-ethyl-4-hydroxy-2-methyl-3(2H)-furanone & $309 \pm 1.88$ & 102 & 3 \\
\hline 2,3-butanedione & $14.2 \pm 0.63$ & 5.2 & 2.5 \\
\hline 2-methoxy-4-vinylphenol & $180 \pm 7.3$ & 81 & 2.2 \\
\hline 2-methoxyphenol & $3.56 \pm 0.24$ & 2.1 & 1.7 \\
\hline 4-hydroxy-2,5-dimethyl-3(2H)-furanone & $113 \pm 2.56$ & 141 & $<1$ \\
\hline 2-methylbutanal & $16.5 \pm 0.19$ & 23 & $<1$ \\
\hline 3-methylbutanoic acid & $213 \pm 48.7$ & 377 & $<1$ \\
\hline 2-phenylacetic acid & $1930 \pm 177$ & 5160 & $<1$ \\
\hline dimethyl sulfide & $16.0 \pm 0.20$ & 48 & $<1$ \\
\hline 2,3-pentanedione & $4.1 \pm 0.13$ & 13 & $<1$ \\
\hline vanillin & $163 \pm 5.76$ & 1490 & $<1$ \\
\hline 3-hydroxy-4,5-dimethyl-2( $5 H)$-furanone & $2.18 \pm 0.04$ & 25 & $<1$ \\
\hline acetic acid & $13,500 \pm 1270$ & 353,000 & $<1$ \\
\hline 2-methoxy-4-methylphenol & $1.15 \pm 0.008$ & 36.8 & $<1$ \\
\hline butanoic acid & $21.7 \pm 3.20$ & 2080 & $<1$ \\
\hline 4-vinylphenol & $10.5 \pm 0.85$ & 2750 & $<1$ \\
\hline 3-methyl-2-butene-1-thiol ${ }^{c}$ & n.d. & n.d. & n.d. \\
\hline
\end{tabular}

${ }^{a}$ Concentrations expressed as the average of three replicates \pm standard deviation. ${ }^{b}$ Orthonasal detection thresholds in the AFB matrix retrieved from our previous study. ${ }^{10}{ }^{c}$ Concentration below the limit of quantitation. n.d. = values could not be determined.

Table 4. QDA Scores for Aroma Attributes in AFB, Wort, and Different Recombinates of the AFB

\begin{tabular}{|c|c|c|c|c|c|c|c|c|c|c|}
\hline samples & $\begin{array}{c}\text { curry, } \\
\text { fenugreek }\end{array}$ & $\begin{array}{l}\text { honey } \\
\text { (hot) }\end{array}$ & floral & $\begin{array}{l}\text { malt, } \\
\text { cereal }\end{array}$ & $\begin{array}{l}\text { hay } \\
\text { (green } \\
\text { tea) }\end{array}$ & yeast & potato & prunes & $\begin{array}{l}\text { dark brown } \\
\text { sugar }\end{array}$ & $\begin{array}{c}\text { apple } \\
\text { (stewed) }\end{array}$ \\
\hline \multicolumn{11}{|c|}{ Sample Set 1} \\
\hline $\mathrm{AFB}$ & $4.8^{\mathrm{b}}$ & $17.8^{\mathrm{a}}$ & $3.6^{\mathrm{bc}}$ & $37.4^{\mathrm{ab}}$ & $12.9^{\mathrm{a}}$ & $16.8^{\mathrm{ab}}$ & $12.7^{\mathrm{a}}$ & $14.7^{\mathrm{a}}$ & $13.7^{\mathrm{a}}$ & $7.0^{\mathrm{a}}$ \\
\hline diluted wort & $3.7^{\mathrm{b}}$ & $15.8^{\mathrm{a}}$ & $2.5^{\mathrm{c}}$ & $41.6^{\mathrm{a}}$ & $11.6^{\mathrm{a}}$ & $20.4^{\mathrm{a}}$ & $14.0^{\mathrm{a}}$ & $14.9^{\mathrm{a}}$ & $14.3^{\mathrm{a}}$ & $6.5^{\mathrm{a}}$ \\
\hline full recombinate & $5.2^{\mathrm{b}}$ & $22.4^{\mathrm{a}}$ & $8.9^{\mathrm{abc}}$ & $31.2^{\mathrm{ab}}$ & $11.8^{\mathrm{a}}$ & $18.8^{\mathrm{a}}$ & $6.2^{\mathrm{a}}$ & $15.6^{\mathrm{a}}$ & $11.6^{\mathrm{a}}$ & $6.1^{\mathrm{a}}$ \\
\hline \multicolumn{11}{|l|}{ omitted recombinates $^{a}$ : } \\
\hline (Z)-4-heptenal & $6.9^{\mathrm{ab}}$ & $20.8^{\mathrm{a}}$ & $9.8^{\mathrm{ab}}$ & $33.2^{\mathrm{ab}}$ & $15.5^{\mathrm{a}}$ & $17.7^{\mathrm{ab}}$ & $6.5^{\mathrm{a}}$ & $19.9^{\mathrm{a}}$ & $14.7^{\mathrm{a}}$ & $8.2^{\mathrm{a}}$ \\
\hline methional & $10.2^{\mathrm{a}}$ & $21.4^{\mathrm{a}}$ & $10.5^{\mathrm{a}}$ & $28.0^{\mathrm{b}}$ & $13.7^{\mathrm{a}}$ & $11.9^{\mathrm{b}}$ & $6.1^{\mathrm{a}}$ & $12.3^{\mathrm{a}}$ & $13.9^{\mathrm{a}}$ & $4.3^{\mathrm{a}}$ \\
\hline 2-methylbutanal and methylpropanal & $6.4^{\mathrm{ab}}$ & $24.6^{\mathrm{a}}$ & $8.7^{\mathrm{abc}}$ & $33.0^{\mathrm{ab}}$ & $12.6^{\mathrm{a}}$ & $17.7^{\mathrm{ab}}$ & $8.2^{\mathrm{a}}$ & $14.5^{\mathrm{a}}$ & $8.9^{\mathrm{a}}$ & $7.5^{\mathrm{a}}$ \\
\hline 3-methyl-2-butene-1-thiol & $4.5^{\mathrm{b}}$ & $22.3^{\mathrm{a}}$ & $9.6^{\mathrm{ab}}$ & $33.3^{\mathrm{ab}}$ & $10.0^{\mathrm{a}}$ & $19.2^{\mathrm{a}}$ & $8.3^{\mathrm{a}}$ & $15.5^{\mathrm{a}}$ & $11.1^{\mathrm{a}}$ & $8.9^{\mathrm{a}}$ \\
\hline 2-phenylethanol & $4.8^{\mathrm{b}}$ & $21.2^{\mathrm{a}}$ & $4.5^{\mathrm{abc}}$ & $35.4^{\mathrm{ab}}$ & $10.6^{\mathrm{a}}$ & $17.3^{\mathrm{ab}}$ & $8.8^{\mathrm{a}}$ & $15.9^{\mathrm{a}}$ & $15.9^{\mathrm{a}}$ & $8.4^{\mathrm{a}}$ \\
\hline $\begin{array}{l}\text { significance of difference between samples } \\
(p \text {-value })\end{array}$ & 0.16 & 0.74 & 0.092 & 0.39 & 0.67 & 0.24 & 0.44 & 0.80 & 0.56 & 0.80 \\
\hline \multicolumn{11}{|c|}{ Sample Set 2} \\
\hline full recombinate & $5.0^{\mathrm{b}}$ & $25.6^{\mathrm{a}}$ & $6.9^{\mathrm{ab}}$ & $35.0^{\mathrm{ab}}$ & $9.7^{\mathrm{ab}}$ & $20.8^{\mathrm{a}}$ & $5.9^{\mathrm{ab}}$ & $15.5^{\mathrm{a}}$ & $13.5^{\mathrm{a}}$ & $7.3^{\mathrm{a}}$ \\
\hline \multicolumn{11}{|l|}{ omitted recombinates $^{a}$ : } \\
\hline 5-ethyl-3-hydroxy-4-methyl-2(5H)-furanone & $3.7^{\mathrm{b}}$ & $18.8^{\mathrm{b}}$ & $9.6^{\mathrm{a}}$ & $31.9^{\mathrm{ab}}$ & $9.1^{\mathrm{ab}}$ & $20.2^{\mathrm{a}}$ & $9.4^{\mathrm{a}}$ & $14.0^{\mathrm{a}}$ & $11.8^{\mathrm{a}}$ & $5.8^{\mathrm{a}}$ \\
\hline$(E)$ - $\beta$-damascenone & $8.9^{\mathrm{ab}}$ & $15.7^{\mathrm{b}}$ & $4.1^{\mathrm{b}}$ & $37.2^{\mathrm{a}}$ & $12.2^{\mathrm{a}}$ & $19.3^{\mathrm{a}}$ & $7.1^{\mathrm{ab}}$ & $17.6^{\mathrm{a}}$ & $13.0^{\mathrm{a}}$ & $4.3^{\mathrm{a}}$ \\
\hline 3-methylbutanal & $6.5^{\mathrm{ab}}$ & $20.3^{\mathrm{ab}}$ & $8.2^{\mathrm{ab}}$ & $29.3^{\mathrm{b}}$ & $10.4^{\mathrm{ab}}$ & $20.5^{\mathrm{a}}$ & $9.4^{\mathrm{a}}$ & $20.0^{\mathrm{a}}$ & $17.5^{\mathrm{a}}$ & $4.6^{\mathrm{a}}$ \\
\hline phenylacetaldehyde & $10.8^{\mathrm{a}}$ & $19.6^{\mathrm{b}}$ & $5.3^{\mathrm{ab}}$ & $35.7^{\mathrm{ab}}$ & $7.5^{\mathrm{b}}$ & $20.7^{\mathrm{a}}$ & $5.0^{\mathrm{b}}$ & $15.3^{\mathrm{a}}$ & $17.8^{\mathrm{a}}$ & $7.7^{\mathrm{a}}$ \\
\hline $\begin{array}{l}\text { significance of difference between samples } \\
(p \text {-value })\end{array}$ & 0.061 & 0.034 & 0.099 & 0.16 & 0.092 & 0.92 & 0.13 & 0.44 & 0.38 & 0.40 \\
\hline
\end{tabular}

${ }^{a}$ In these recombinates, the compound named has been omitted from the mixture. Samples with the same superscript letters (within a column and a sample set) indicate that the samples were not found to differ significantly for the specified attribute $(p=0.05)$.

and so forth. Another reason would be the different release of flavor compounds from the foodstuff because of the interaction with the other constituents of the matrix. ${ }^{24}$
Aroma Recombination and Individual Contributions by Omitted Recombinates. After the odor-active compounds had been identified and quantitated, a recombinate was 
prepared by mixing them, at the concentrations that were present in the AFB (Table 2), into the artificial AFB-like matrix used in our previous study. ${ }^{10}$ Although some of the compounds were present at concentrations below their thresholds, they were included in the recombinate because of the demonstrated effect of subthreshold compounds on the overall aroma of a foodstuff. ${ }^{22}$ 3-Methyl-2-butene-1-thiol was also added to the recombinate even though its concentration could not be determined analytically. Recombinates containing different concentrations of this compound (data not shown) were presented to the panelists, and they chose the one where the aroma was closest to the AFB of reference.

Along with the full recombinate, nine omitted recombinates were assessed in two sets of samples by the sensory panel. Table 4 shows the QDA scores for aroma descriptors in AFB, diluted wort (50\% in filtered tap water), and different recombinates. The panelists provided a useful vocabulary for breaking down the concept of "worty aroma" or "wortiness" into single descriptors because the 10 descriptors were all used to score the wort. Moreover, the AFB was a good example of a worty beer as there was no significant difference in scores for any of the attributes between the AFB and the $50 \%$ wort sample $(p>0.05)$. The full recombinate was also found to have no significant difference compared to the AFB, indicating that the identification and quantitation of the aroma compounds had been good enough to prepare a recombinate which reproduced the aroma of the AFB.

Considering all the omission samples, there were significant differences $(p<0.05)$ between the sample for the attribute "floral" for the first group of samples and "honey (hot)" for the second group. Other attributes were significantly different at a higher probability value $(p<0.1)$, such as, "floral", "curry, fenugreek", and "hay (green tea)" in sample set 2. QDA was chosen as the most appropriate sensory method for assessing the samples so that the effect that individual flavor compounds had on single aroma notes could be observed. In order to verify whether samples significantly differed in aroma overall, sensory discrimination tests (like triangle test or 3-AFC) could be carried out, but this would not have clarified the effects on individual aroma attributes.

The absence of methional, 5-ethyl-3-hydroxy-4-methyl$2(5 H)$-furanone, $(E)$ - $\beta$-damascenone, 3 -methylbutanal, and phenylacetaldehyde produced the greatest differences in QDA scores for certain attributes compared to the full recombinate (Table 4). These five compounds were the ones with highest $\mathrm{OAV}$, which suggests that this parameter was a good estimation of the potency of aroma compounds in food. (E)- $\beta$-Damascenone, 5-ethyl-3-hydroxy-4-methyl-2( $5 H)$-furanone, phenylacetaldehyde, and 3-methylbutanal contributed to the "hot honey" character of the AFB because a significantly lower score was observed when these compounds were absent. In the case of 3-methybutanal, the difference was significant at a higher probability value $(p=0.081)$, according to the probability values from Fisher's test (data not shown). The first three have a sweet character to them and are likely to be positively influencing the hot honey note. On the other hand, 3-methylbutanal has a malty grainy note, and its role in the hot honey note is less clear. The "yeast" note was caused by methional, but omission of methional also led to an increase in the perception of the "curry, fenugreek" note. 3-Methylbutanal and methional were the main contributors to "malt, cereal"; their absence produced the lowest score for this attribute. However, these differences to the full recombinate were not significant, even when using a higher threshold $p$-value $(p<$ $0.10)$.

The absence of 2-methylbutanal together with methylpropanal did not produce any significant differences to the full recombinate, and thus these two compounds were regarded as making little contribution to the overall aroma of the AFB. This is different to the findings of Perpète and Collin, in which 2-methylbutanal was considered a key contributor to the worty flavor of AFB resulting from cold-contact fermentations. ${ }^{9}$ In certain cases, the absence of a compound boosted the scores of other attributes. This can be explained because of the masking effect of the absent compound for that attribute, that is, the presence of that compound can reduce the impression of another aroma note to which it is not contributing directly. For instance, the absence of methional and phenylacetaldehyde increased the perception of the "curry, fenugreek" note, which means that these compounds were covering this note when present.

Origins of the Key Aroma Compounds. Among the compounds with higher OAV, most of them were Strecker aldehydes, such as methional, 3-methylbutanal, phenylacetaldehyde, and methylpropanal. These aldehydes derive from the amino acids methionine, leucine, phenylalanine, and valine, respectively. ${ }^{8}$ These compounds are usually reduced by yeast so are present in lager beers at much lower concentrations than in AFB brewed by cold-contact fermentation. Kishimoto et al. reported the concentrations of 2-methylbutanal, 3-methylbutanal, methional, and phenylacetaldehyde in a Pilsner beer to be $1.7,4.9,1.2$, and $4.5 \mu \mathrm{g} / \mathrm{L}$, respectively, ${ }^{22}$ whereas in our AFB, these were $16.5,38.4,85.4$, and $160 \mu \mathrm{g} / \mathrm{L}$. The contribution of these compounds to the overall aroma of Pilsner beer was almost insignificant, while in Bavarian wheat beers, the only Strecker aldehyde found at a concentration higher than its threshold was 3-methylbutanal. ${ }^{11}$ These Strecker aldehydes are already formed during malt kilning ${ }^{23,25}$ but also during mashing and wort boiling through the Maillard reaction in both cases. ${ }^{26}$

$(E)-\beta$-Damascenone has been found in commercial Belgian beers, ${ }^{27,28}$ wheat beers, ${ }^{11}$ unhopped wort, ${ }^{29}$ and barley malt. ${ }^{23}$ Langos et al. speculated that this aroma compound might be liberated from a glycosidic precursor. ${ }^{11}$ Chevance et al. demonstrated, by treating a beer sample with $\beta$-glycosidase, that the origin of $(E)-\beta$-damascenone in beer was partially attributed to hydrolysis of glycosides, but this alleged glycoside was not identified. ${ }^{28}$ The authors also suggested an alternative source of this norisoprenoid from the degradation of the carotenoid neoxanthin. According to Kollmannsberger et al., (E)- $\beta$-damascenone can also originate from the $\beta$-D-glucoside of 3 -hydroxy- $\beta$-damascone present in hops. ${ }^{30}$ On the other hand, 5-ethyl-3-hydroxy-4-methyl-2( $5 H)$-furanone, also known as "abhexon" or "maple furanone", has been found in Pilsner beer, ${ }^{22}$ Gueuze beer, ${ }^{31}$ barley malt, ${ }^{23}$ as well as other foodstuffs such as coffee. ${ }^{32}$ Several formation pathways have been proposed for this compound. Sulser et al. proposed that 5ethyl-3-hydroxy-4-methyl-2(5H)-furanone can be formed from the aldol condensation of two molecules of $\alpha$-ketobutyric acid originated from the degradation of threonine. ${ }^{33}$ Another possible formation mechanism involves the condensation of $\alpha$-ketobutyric acid and propanal. ${ }^{34}$

In the present study, 27 odor-active volatile compounds in an AFB were identified and quantitated, and a vocabulary for the description of "worty aroma" was developed. The aroma of AFB was reproduced by a recombinate containing 27 aroma 
compounds at the concentrations present in the beer. Five of these were found to be key aroma compounds: 5-ethyl-3hydroxy-4-methyl-2( $5 H)$-furanone, $(E)$ - $\beta$-damascenone, methional, 3-methylbutanal, and phenylacetaldehyde, which confirmed our initial hypothesis of this piece of research that compounds other than the already recognized Strecker aldehydes also make an important contribution to the aroma of wort. The role of 5-ethyl-3-hydroxy-4-methyl-2(5H)furanone and $(E)-\beta$-damascenone was reported in detail for the first time and confirmed through the sensory evaluation of omitted recombinates. The formation of 5-ethyl-3-hydroxy-4methyl-2(5H)-furanone was attributed to the Maillard reaction, whereas the origin of $(E)$ - $\beta$-damascenone in beer is not clear yet. The findings from this study can be of great interest to the brewing industry in order to design strategies to reduce the levels of these compounds responsible of the worty character of AFB, such as, the selective adsorption of Strecker aldehydes, $^{35}$ and thus improve their quality and consumer acceptability.

\section{ASSOCIATED CONTENT}

\section{SI Supporting Information}

The Supporting Information is available free of charge at https://pubs.acs.org/doi/10.1021/acs.jafc.0c03902.

Odor-active volatiles in SAFE extracts (basic/neutral and acidic fractions) of AFB and wort (PDF)

\section{AUTHOR INFORMATION}

\section{Corresponding Author}

Jane K. Parker - Department of Food and Nutritional Sciences, University of Reading, Reading RG6 6AP, U.K.; (1) orcid.org/ 0000-0003-4121-5481; Phone: +44 118378 7455;

Email: j.k.parker@reading.ac.uk

\section{Authors}

José A. Piornos - Department of Food and Nutritional Sciences, University of Reading, Reading RG6 6AP, U.K.

Dimitrios P. Balagiannis - Department of Food and Nutritional Sciences, University of Reading, Reading RG6 6AP, U.K.

Lisa Methven - Department of Food and Nutritional Sciences, University of Reading, Reading RG6 6AP, U.K.

Elisabeth Koussissi - Global Innovation \& Research, Heineken Supply Chain BV, Zoeterwoude 2382 PH, The Netherlands

Eric Brouwer - Global Innovation \& Research, Heineken Supply Chain BV, Zoeterwoude 2382 PH, The Netherlands

Complete contact information is available at:

https://pubs.acs.org/10.1021/acs.jafc.0c03902

\section{Notes}

The authors declare no competing financial interest.

\section{ACKNOWLEDGMENTS}

This study has been funded by Heineken Supply Chain BV. We would like to acknowledge Compusense Inc. for provision of sensory software under an academic consortium agreement as well as all the panelists who participated in this study. We also want to thank Dr Tolgahan Kocadağlı and Dr Neslihan Göncüoğlu Taş for their advice on LC-ESI-MS/MS, and Dr. Omobolanle Oloyede for advice on the analysis of sensory data.

\section{REFERENCES}

(1) Andrés-Iglesias, C.; Blanco, C. A.; García-Serna, J.; Pando, V.; Montero, O. Volatile Compound Profiling in Commercial Lager Regular Beers and Derived Alcohol-Free Beers After Dealcoholization by Vacuum Distillation. Food Anal. Methods 2016, 9, 3230-3241.

(2) The Brewers of Europe. The Contribution Made by Beer to the European Economy, Brussels, 2016.

(3) Brányik, T.; Silva, D. P.; Baszczyňski, M.; Lehnert, R.; Almeida e Silva, J. B. A Review of Methods of Low Alcohol and Alcohol-Free Beer Production. J. Food Eng. 2012, 108, 493-506.

(4) Catarino, M.; Mendes, A.; Madeira, L.; Ferreira, A. Beer Dealcoholization by Reverse Osmosis. Desalination 2006, 200, 397399.

(5) Strejc, J.; Siříštová, L.; Karabín, M.; Almeida e Silva, J. B.; Brányik, T. Production of Alcohol-Free Beer with Elevated Amounts of Flavouring Compounds Using Lager Yeast Mutants. J. Inst. Brew. 2013, 119, 149-155.

(6) Schur, F. Process for the Preparation of Alcohol-Free Drinks with a Yeast Aroma. U.S. Patent 4,661,355A, 1987.

(7) Pires, E. J.; Teixeira, J. A.; Brányik, T.; Vicente, A. A. Yeast: The Soul of Beer's Aroma - A Review of Flavour-Active Esters and Higher Alcohols Produced by the Brewing Yeast. Appl. Microbiol. Biotechnol. 2014, 98, 1937-1949.

(8) Perpète, P.; Collin, S. Fate of the Worty Flavours in a Cold Contact Fermentation. Food Chem. 1999, 66, 359-363.

(9) Perpète, P.; Collin, S. Contribution of 3-Methylthiopropionaldehyde to the Worty Flavor of Alcohol-Free Beers. J. Agric. Food Chem. 1999, 47, 2374-2378.

(10) Piornos, J. A.; Delgado, A.; de La Burgade, R. C. J.; Methven, L.; Balagiannis, D. P.; Koussissi, E.; Brouwer, E.; Parker, J. K. Orthonasal and Retronasal Detection Thresholds of 26 Aroma Compounds in a Model Alcohol-Free Beer: Effect of Threshold Calculation Method. Food Res. Int. 2019, 123, 317-326.

(11) Langos, D.; Granvogl, M.; Schieberle, P. Characterization of the Key Aroma Compounds in Two Bavarian Wheat Beers by Means of the Sensomics Approach. J. Agric. Food Chem. 2013, 61, 1130311311.

(12) Fritsch, H. T.; Schieberle, P. Identification Based on Quantitative Measurements and Aroma Recombination of the Character Impact Odorants in a Bavarian Pilsner-Type Beer. J. Agric. Food Chem. 2005, 53, 7544-7551.

(13) Engel, W.; Bahr, W.; Schieberle, P. Solvent Assisted Flavour Evaporation - A New and Versatile Technique for the Careful and Direct Isolation of Aroma Compounds from Complex Food Matrices. Eur. Food Res. Technol. 1999, 209, 237-241.

(14) Lignou, S.; Parker, J. K.; Oruna-Concha, M. J.; Mottram, D. S. Flavour Profiles of Three Novel Acidic Varieties of Muskmelon (Cucumis melo L.). Food Chem. 2013, 139, 1152-1160.

(15) Elmore, J. S.; Mottram, D. S.; Hierro, E. Two-Fibre Solid-Phase Microextraction Combined with Gas Chromatography-Mass Spectrometry for the Analysis of Volatile Aroma Compounds in Cooked Pork. J. Chromatogr. A 2001, 905, 233-240.

(16) Saison, D.; De Schutter, D. P.; Uyttenhove, B.; Delvaux, F.; Delvaux, F. R. Contribution of Staling Compounds to the Aged Flavour of Lager Beer by Studying Their Flavour Thresholds. Food Chem. 2009, 114, 1206-1215.

(17) Fiorini, D.; Pacetti, D.; Gabbianelli, R.; Gabrielli, S.; Ballini, R. A Salting out System for Improving the Efficiency of the Headspace Solid-Phase Microextraction of Short and Medium Chain Free Fatty Acids. J. Chromatogr. A 2015, 1409, 282-287.

(18) Beaudry, F.; Ross, A.; Vachon, P. Development of a LC-ESI/ MS/MS Assay for the Quantification of Vanillin Using a Simple offLine Dansyl Chloride Derivatization Reaction to Enhance Signal Intensity. Biomed. Chromatogr. 2007, 21, 113-115.

(19) Lusk, L. T.; Murakami, A.; Nielsen, L.; Kay, S.; Ryder, D. Beer Photooxidation Creates Two Compounds with Aromas Indistinguishable from 3-Methyl-2-Butene-1-Thiol. J. Am. Soc. Brew. Chem. 2009, 67, 189-192. 
(20) Anderson, R. J.; Howard, G. A. The Origin and Occurrence of Volatile Sulphur Compounds in British Ales and Lagers. J. Inst. Brew. 1974, 80, 357-370.

(21) Vesely, P.; Lusk, L.; Basarova, G.; Seabrooks, J.; Ryder, D. Analysis of Aldehydes in Beer Using Solid-Phase Microextraction with On-Fiber Derivatization and Gas Chromatography/Mass Spectrometry. J. Agric. Food Chem. 2003, 51, 6941-6944.

(22) Kishimoto, T.; Noba, S.; Yako, N.; Kobayashi, M.; Watanabe, T. Simulation of Pilsner-Type Beer Aroma Using 76 Odor-Active Compounds. J. Biosci. Bioeng. 2018, 126, 330-338.

(23) Fickert, B.; Schieberle, P. Identification of the Key Odorants in Barley Malt (Caramalt) Using GC/MS Techniques and Odour Dilution Analyses. Food Nahrung 1998, 42, 371-375.

(24) Wagner, J.; Granvogl, M.; Schieberle, P. Characterization of the Key Aroma Compounds in Raw Licorice (Glycyrrhiza glabra L.) by Means of Molecular Sensory Science. J. Agric. Food Chem. 2016, 64, 8388-8396.

(25) Beal, A. D.; Mottram, D. S. Compounds Contributing to the Characteristic Aroma of Malted Barley. J. Agric. Food Chem. 1994, 42, $2880-2884$.

(26) Wietstock, P. C.; Baldus, M.; Öhlschläger, M.; Methner, F.-J. Hop Constituents Suppress the Formation of 3-Methylbutanal and 2Furfural in Wort-like Model Solutions. J. Am. Soc. Brew. Chem. 2017, $75,41-51$.

(27) Schieberle, P. Primary odorants of pale lager beer. Z. Lebensm.Unters. Forsch. 1991, 193, 558-565.

(28) Chevance, F.; Guyot-Declerck, C.; Dupont, J.; Collin, S. Investigation of the $\beta$-Damascenone Level in Fresh and Aged Commercial Beers. J. Agric. Food Chem. 2002, 50, 3818-3821.

(29) De Schutter, D. P.; Saison, D.; Delvaux, F.; Derdelinckx, G.; Rock, J.-M.; Neven, H.; Delvaux, F. R. Characterization of Volatiles in Unhopped Wort. J. Agric. Food Chem. 2008, 56, 246-254.

(30) Kollmannsberger, H.; Biendl, M.; Nitz, S. Occurrence of Glycosidically Bound Flavour Compounds in Hops, Hop Products and Beer. Monatsschr. Brauwiss. 2006, 59, 83-89.

(31) Scholtes, C.; Nizet, S.; Collin, S. Occurrence of Sotolon, Abhexon and Theaspirane-Derived Molecules in Gueuze Beers. Chemical Similarities with Yellow Wines. J. Inst. Brew. 2012, 118, 223-229.

(32) Blank, I.; Sen, A.; Grosch, W. Potent Odorants of the Roasted Powder and Brew of Arabica Coffee. Z. Lebensm.-Unters. Forsch. 1992, 195, 239-245.

(33) Sulser, H.; De Pizzol, J.; Büchi, W. A Probable Flavoring Principle in Vegetable-Protein Hydrolysates. J. Food Sci. 1967, 32, 611-615.

(34) Collin, S.; Nizet, S.; Claeys Bouuaert, T.; Despatures, P.-M. Main Odorants in Jura Flor-Sherry Wines. Relative Contributions of Sotolon, Abhexon, and Theaspirane-Derived Compounds. J. Agric. Food Chem. 2012, 60, 380-387.

(35) Gernat, D. C.; Brouwer, E.; Ottens, M. Aldehydes as Wort OffFlavours in Alcohol-Free Beers-Origin and Control. Food Bioprocess Technol. 2020, 13, 195-216.

(36) Kishimoto, T.; Wanikawa, A.; Kono, K.; Shibata, K. Comparison of the Odor-Active Compounds in Unhopped Beer and Beers Hopped with Different Hop Varieties. J. Agric. Food Chem. 2006, 54, 8855-8861.

(37) Vermeulen, C.; Lejeune, I.; Tran, T. T. H.; Collin, S. Occurrence of Polyfunctional Thiols in Fresh Lager Beers. J. Agric. Food Chem. 2006, 54, 5061-5068. 